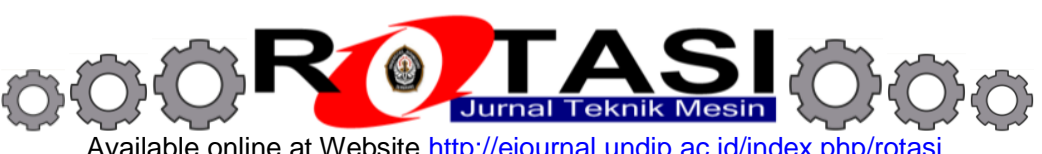

Available online at Website http://ejournal.undip.ac.id/index.php/rotas

\title{
ANALISA RUNNING-IN RODA GIGI TRANSMISI PRODUK USAHA KECIL MENENGAH
}

\author{
*Taufiq Hidayat, Nana Supriyana, Petrus Londa, Jamari, Joga Dharma Setiawan \\ Program Studi Magister Teknik Mesin, Fakultas Teknik, Universitas Diponegoro \\ Jl. Prof. Sudharto, SH., Tembalang-Semarang 50275, Telp. +62247460059 \\ *E-mail: ophiqhd@gmail.com
}

\begin{abstract}
ABSTRAK
Saat ini kecenderungan industri roda gigi adalah fokus pada peningkatan efisiensi roda gigi transmisi. Efisiensi roda gigi transmisi menurun dikarenakan kontak load dan unload, seals, pelumas, dan bantalan. Salah satu cara untuk meminimalkan kerugian tersebut adalah dengan menurunkan viskositas pelumas. Cara ini akan menurunkan kecepatan kerugian. Tetapi kerugian karena beban akan meningkat. Untuk menghindari ini, rasio antara ketebalan lapisan pelumas dan kekasaran permukaan harus dijaga, dimana dapat dipenuhi dengan membuat permukaan roda gigi lebih halus.

Tujuan penelitian ini adalah menganalisa proses running-in roda gigi produk lokal UKM. Sebagai pembanding dilakukan running-in roda gigi produk OEM. Pengujian yang dilakukan adalah uji kekerasan dan kekasaran permukaan awal dan selama proses running-in. Eksperimen dilakukan pada roda gigi AHM dan UKM. Proses running-in berjalan pada $600 \mathrm{rpm}$ dan beban tetap $10 \mathrm{~kg}$.

Roda gigi yang memiliki nilai kekasaran permukaan yang tinggi akan menimbulkan koefisien gesek yang tinggi pula. Roda gigi AHM memiliki kekasaran permukaan antara 0,5-0,8 $\mu$ m. Kekasaran roda gigi produk UKM antara 0,8-1,2 $\mu \mathrm{m}$. Roda gigi produk AHM memiliki koefisien gesek 0,41, sedangkan roda gigi produk UKM memiliki koefisien gesek 0,43. Roda gigi produk AHM mempunyai waktu running-in sampai tercapai keadaan steady state selama 45 menit. Sedangkan roda gigi produk UKM mempunyai waktu running-in 40 menit. Dapat disimpulkan bahwa roda gigi produk UKM mempunyai kekasaran permukaan yang lebih tinggi dibanding produk AHM, sehingga koefisien geseknya lebih tinggi pula. Tetapi dari segi waktu runnning-in lebih cepat dikarenakan kekerasan permukaan lebih rendah dibanding produk AHM.
\end{abstract}

Kata kunci: running-in, roda gigi, kekasaran permukaan.

\section{PENDAHULUAN}

Roda gigi dan transmisi roda gigi digunakan untuk mengubah karakteristik gerakan, baik perubahan gerakan putaran ke linier, linier ke putaran, atau hanya perubahan pada torsi dan kecepatan dari poros (putaran ke putaran). Transmisi roda gigi termasuk penemuan tua yang telah berkembang selama berabad-abad dalam hal profil dan kompleksitas transmisi.

Saat ini kecenderungan industri roda gigi adalah fokus pada peningkatan efisiensi roda gigi transmisi. Efisiensi roda gigi transmisi menurun dikarenakan kontak load dan unload, seals, pelumas, dan bantalan. Salah satu cara untuk meminimalkan kerugian tersebut adalah dengan menurunkan viskositas pelumas. Cara ini akan menurunkan kecepatan kerugian. Tetapi kerugian karena beban akan meningkat. Untuk menghindari ini, rasio antara ketebalan lapisan pelumas dan kekasaran permukaan harus dijaga, dimana dapat dipenuhi dengan membuat permukaan roda gigi lebih halus.

Area kontak antara roda gigi memiliki bentuk segiempat (rectangular) dan bisa di kelompokkan dalam masalah kontak garis (line contact problem) seperti ditunjukkan pada gambar 1. Kontak yang terjadi pada roda gigi berupa kontak non-formal dan termasuk dalam deformasi elastis. Kontak non-formal dan deformasi elastis dikategorikan dalam kontak garis Elasto Hydrodynamic Lubrication (EHL) [1].

Fase running-in merupakan fase pertama saat dua permukaan baru (fresh) hasil proses pemesinan diberi beban kontak dan saling bergerak relatif satu dengan yang lain [2]. Pada kenyataannya, permukaan roda gigi tidaklah halus. Kontak sebenarnya yang terjadi adalah antar asperiti pada permukaan roda gigi. Tekanan kontak dan beban kontak mempunyai peranan penting pada koefisien gesek dan daya yang hilang.

Pengertian tentang running-in dijelaskan oleh beberapa ahli antara lain standar GOST (USSR) mendefinisikan running-in sebagai "Perubahan geometri permukaan yang mengalami gesekan dan perubahan dalam fisik-mekanik lapisan-lapisan permukaan material selama periode sliding awal, yang pada umumnya terjadi dengan sendirinya, dengan mengasumsikan kondisi eksternal konstan, dalam berkurangnya kerja gesek, temperatur, dan laju keausan [3]. Summersmith mendefinisikan running-in sebagai: "Hilangnya puncak-puncak tinggi (asperity) pada permukaan yang mengalami kontak akibat keausan atau deformasi plastik saat kondisi kerja yang terkontrol dengan memberikan penyesuaian yang cepat". Gambar 2 menunjukkan perubahan topografi permukaan saat sebelum mengalami kontak (fresh surafce) dan setelah mengalami running-in. Running-in terjadi dalam periode pertama waktu-pakai kontak rolling atau sliding pada system yang terlubrikasi [4]. Penelitian yang sedang berkembang hingga saat ini belum banyak membahas mengenai running-in pada kondisi rolling-sliding contact. Pada kenyataannya, komponen 
mesin seperti roda gigi dan bantalan sangat memerlukan analisis running-in untuk kontak rolling-sliding yang baik sehingga pada pemakaian selanjutnya dapat berfungsi optimal.

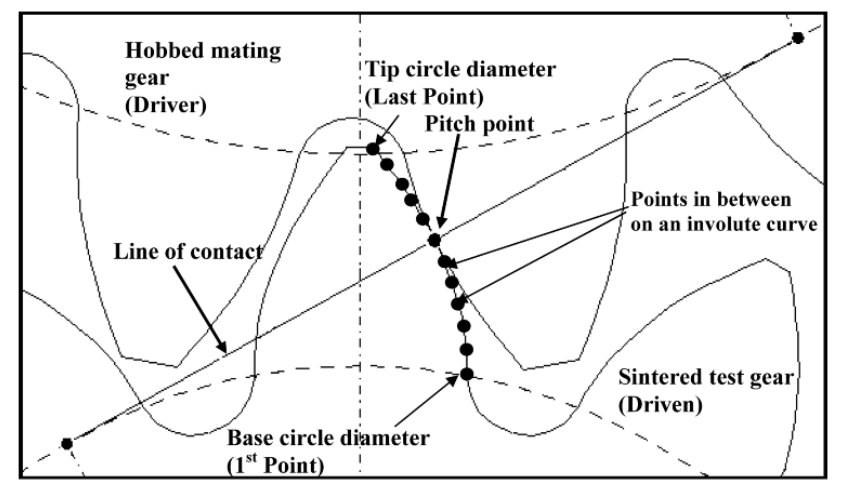

Gambar 1. Titik kontak pada roda gigi [5]

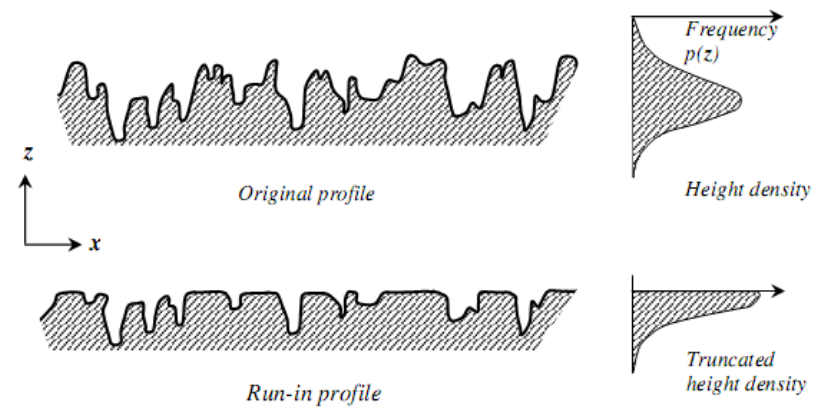

Gambar 2. Efek dari running-in terhadap topografi permukaan awal suatu komponen [6].

Fase ini sangat penting untuk komponen yang saling kontak agar dapat saling menyesuaikan, mengurangi missalignment serta membentuk clearance yang tepat. Selain pemberian beban dan waktu tempuh, fase running-in juga ditentukan oleh kualitas permukaan awal komponen sebelum fase ini diberikan. Usaha Kecil Menengah (UKM) yang memproduksi roda gigi transmisi diharapkan memproduksi roda gigi yang memiliki kualitas kekasaran permukaan yang baik.

Running-in merupakan keausan awal dan deformasi plastik dari permukaan kontak, dimulai dari keadaan awal dari permukaan kontak yang terbentuk pada proses manufaktur dan berlangsung selama beberapa waktu singkat. Periode running-in didefinisikan sebagai periode waktu sampai tercapai fasa steady-state keausan ringan atau sampai fasa steady-state gesekan [7]. Secara konsekuen tidak menjamin bahwa kehalusan permukaan sejalan dengan koefisien gesek steady-state. Blau mengidentifikasikan delapan diagram keadaan running-in yang berbeda pada saat mengekstrak data dari berbagai penelitian yang dilakukannya. Bentuk kurva yang berbeda-beda ditunjukkan pada gambar 3, menunjukkan variasi dikarenakan kontribusi fenomena fisik yang berbeda seperti oksidasi, deformasi plastik dan perpindahan geram-geram keausan. Reaksi terjadi dan dikelompokkan ke dalam kurva running-in yang spesifik, semuanya di kendalikan oleh faktor lingkungan, tipe gerakan, kecepatan, beban, topografi permukaan dan lain-lain. Hal ini berarti jika ingin melakukan running-in yang terkendali harus didesain menurut kondisi running-in yang diinginkan: variasi beban, kecepatan dan faktor lingkungan. Dari uraian latar belakang di atas, maka perlu dilakukan pengujian running-in roda gigi produk UKM dibandingkan dengan roda gigi produk AHM.

Penelitian tentang running-in roda gigi secara khusus dilakukan oleh Sjoberg, Björklund dan Olofsson dengan judul "The influence of manufacturing method on the running-in of gears" [8]. Penelitiannya fokus pada perbedaan metode produksi roda gigi, terutama kontribusinya terhadap proses running-in, pengaruh karakter permukaan, dengan pandangan meningkatnya efisiensi gearboks. Metode manufaktur dasar yang dilakukan adalah dengan hobbing. Selanjutnya dilakukan metode honing, shaving dan grinding. Kesimpulan utama dari penelitiannya adalah rasio area kontak menggambarkan bagaimana topografi permukaan mempengaruhi kontak. Topografi kontak akibat metode manufaktur memiliki pengaruh yang signifikan pada rasio area kontak. Metode shaving memiliki rasio area kontak yang terbesar dan seharusnya dijadikan pilihan terbaik.

Evans, dkk [9] melakukan penelitian tentang pengaruh kekasaran permukaan pada kontak roda gigi dengan judul "Deterministic mixed lubrication modelling using roughness measurements in gear applications". Makalah tersebut membahas pengaruh kekasaran permukaan ketika ketebalan film pelumas elastohydrodynamic dibentuk antara permukaan gigi lebih tipis dibandingkan dengan kekasaran. Untuk kondisi seperti lapisan film tipis, perubahan kekasaran menyebabkan kontak elastohydrodynamic antara gigi menjadi sangat tinggi secara alami. 
Paper tersebut mereview pendekatan yang digunakan untuk mempelajari masalah ini dan menggambarkan pendekatan yang digabungkan untuk memecahkan persamaan elastis dan hidrodinamik. Hal ini memungkinkan solusi numerik dapat diperoleh untuk kondisi ekstrim sehingga kontak transient yang berkaitan dengan mixed lubrication dapat diprediksi dalam skema solusi numerik terpadu. Hasil yang diperoleh dari analisis semacam itu disajikan termasuk model kelelahan permukaan dan perhitungan energi regangan perhitungan pemodelan dan kontak.

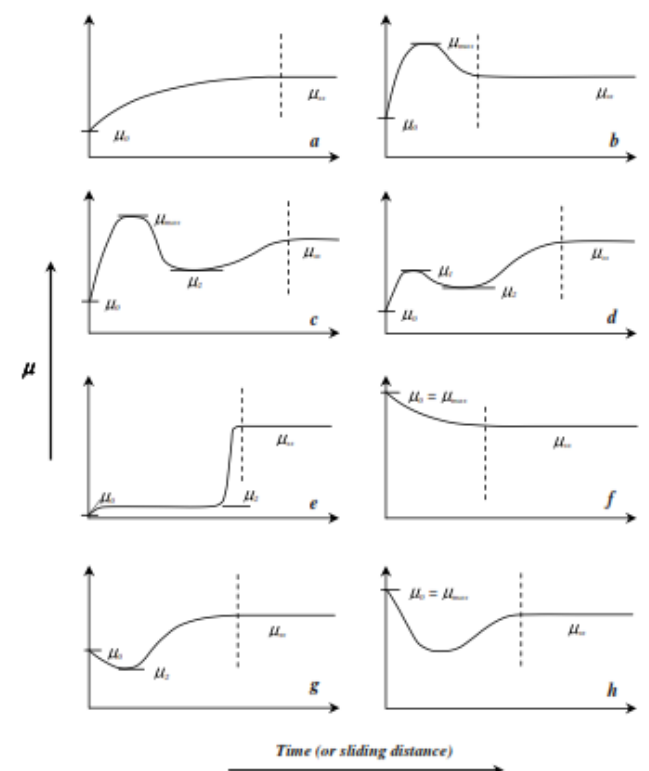

Gambar 3. Beberapa bentuk kurva running-in [10].

\section{METODOLOGI PENELITIAN}

Roda gigi yang digunakan dalam penelitian ini adalah roda gigi transmisi tingkat kedua dari sepeda motor Honda Supra X 100cc. Part number 23441-KEV-901 gear, countershaft second (29t). Foto roda gigi transmisi AHM ditunjukkan pada gambar 4a. Sedangkan roda gigi transmisi buatan UKM diperlihatkan pada gambar 4b. Untuk material diusahakan komposisi kimia nya mendekati komposisi kimia produk AHM. Material roda gigi buatan UKM adalah baja paduan (alloy steel) SCM440H yang memang diperuntukkan untuk bahan roda gigi transmisi.

Alat uji yang digunakan adalah gear test rig dengan menggunakan dua buah motor listrik masing-masing $1 \mathrm{hp}$ $2800 \mathrm{rpm} 3$ phasa yang bisa diatur putarannya. Putaran spesimen bisa diatur antara 100-2800 rpm. Beban torsi bisa diatur pada salah satu poros spesimen. Data akuisisi menggunakan software LabView 7.1. Alat uji roda gigi ditunjukkan pada gambar 5a. Program LabView ditunjukkan seperti pada gambar 5b.

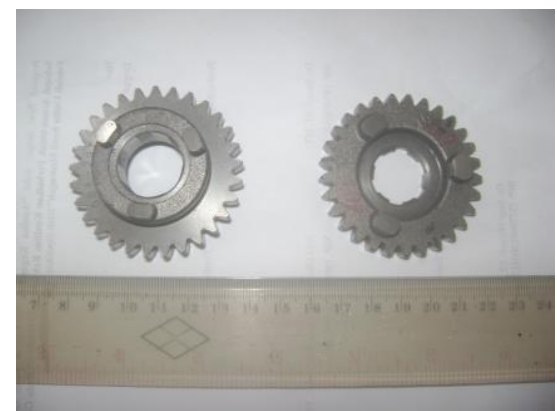

(a)

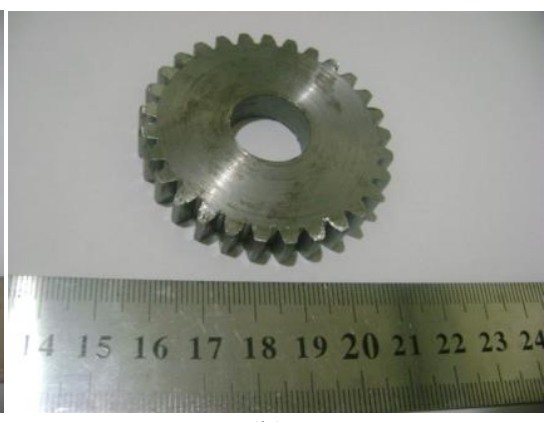

(b)

Gambar 4. (a). Roda gigi produk AHM, (b). Roda gigi produk UKM 


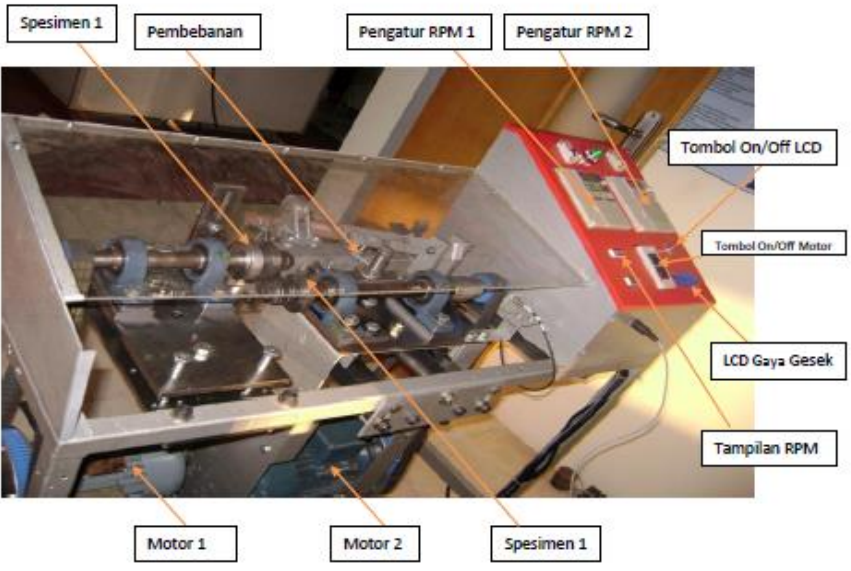

(a)

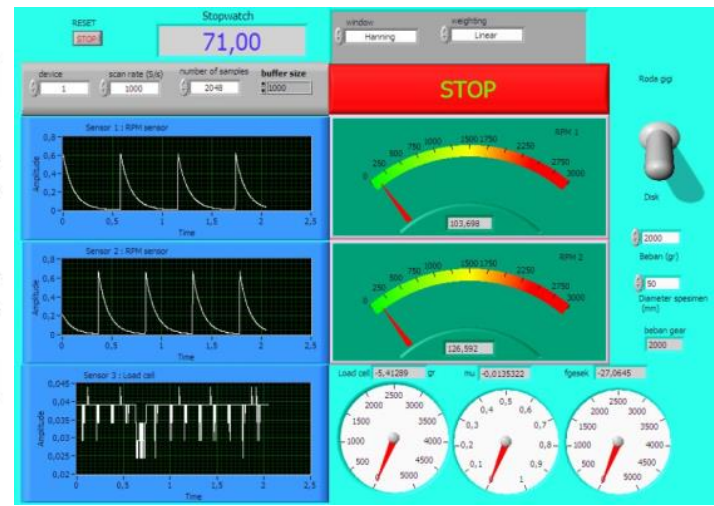

(b)

Gambar 5. (a). Alat uji gear, (b). Tampilan program LabView untuk data akuisisi

Penelitian diawali dengan pengujian kekerasan roda gigi. Kemudian memasangkan spesimen roda gigi pada masing-masing poros. Sebelum melakukan eksperimen terlebih dahulu diukur kekasaran permukaan awal seperti pada gambar 6. Mensetting rpm poros penggerak pada $600 \mathrm{rpm}$. Proses running-in berjalan pada $600 \mathrm{rpm}$ dengan beban torsi tetap yaitu $10 \mathrm{~kg}$. Selama proses running-in roda gigi diukur kekasaran permukaan pada area kontak setiap 5 menit. Koefisien gesek akan ditampilkan di layar secara otomatis. Sehingga diketahui nilai kekasaran permukaan dan koefisien gesek selama waktu tertentu.
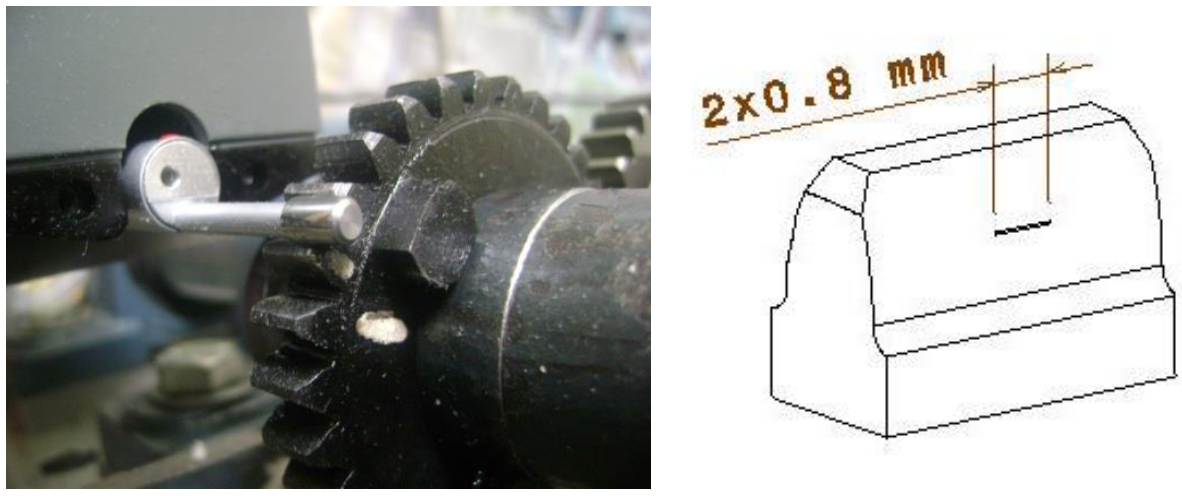

Gambar 6. Posisi pengukuran kekasaran permukaan roda gigi

Posisi pengukuran kekerasan ditunjukkan pada gambar 7. Diagram alir penelitian ditunjukkan pada gambar 8.
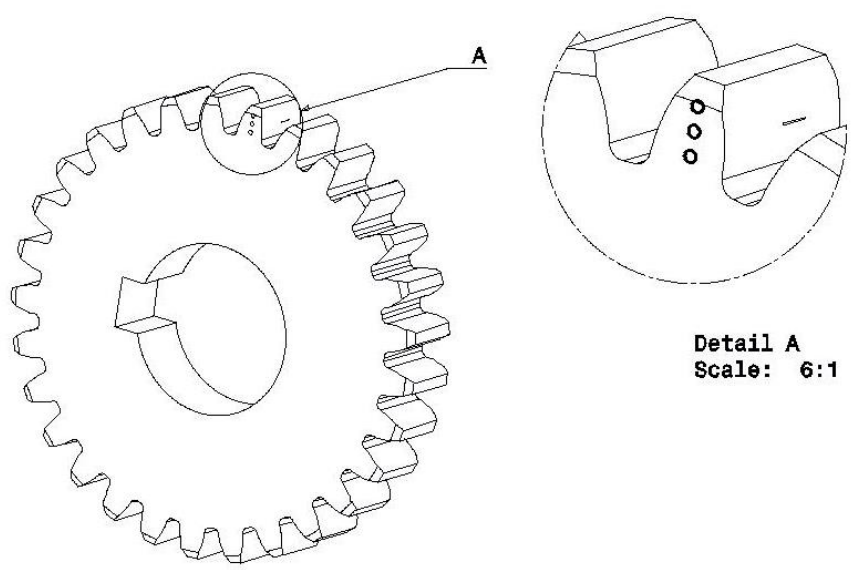

Gambar 7. Posisi pengukuran kekerasan permukaan roda gigi 


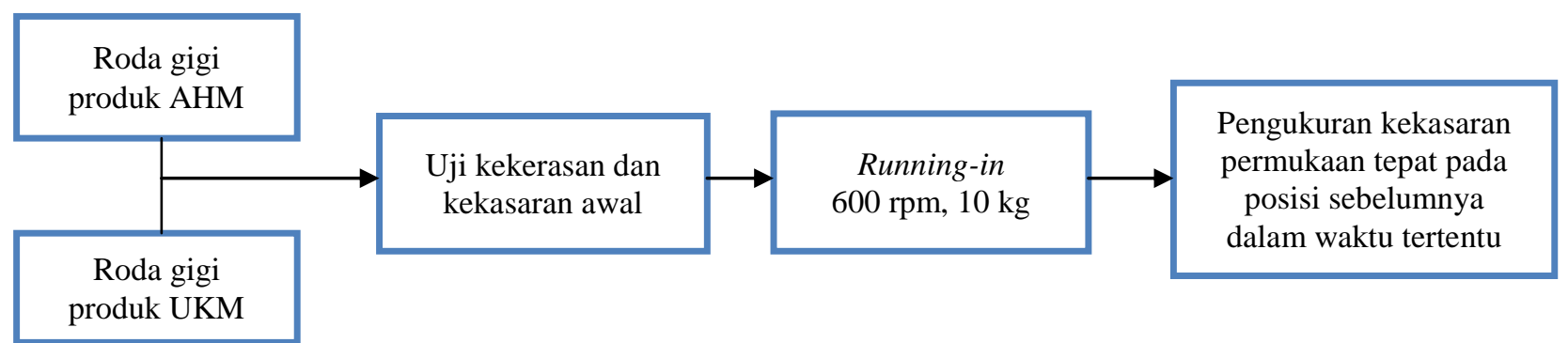

Gambar 8. Diagram alir penelitian

\section{HASIL DAN PEMBAHASAN}

Pengujian kekerasan dilakukan menggunakan tipe Rockwell Hardness dengan indenter bola baja dengan beban $60 \mathrm{~kg}$. Hasilnya ditunjukkan pada tabel 1.

Tabel 1. Hasil pengujian kekerasan [HRA].

\begin{tabular}{ccc}
\hline Jarak dari tepi gigi $[\mathrm{mm}]$ & AHM & UKM \\
\hline 1 & 80 & 61 \\
2 & 79 & 60,5 \\
3 & 79 & 59,5 \\
\hline
\end{tabular}

Dari hasil pengujian kekerasan tampak bahwa kekerasan roda gigi UKM lebih rendah dibandingkan kekerasan roda gigi AHM. Dan kekerasan produk UKM merata dari tepi sampai ke tengah, dikarenakan material homogen dan belum mengalami pengerasan permukaan. Sedangkan produk AHM sudah mengalami pengerasan permukaan yang ditandai dengan kekerasan di tepi gigi lebih tinggi dibandingkan di tengah.

Proses running-in roda gigi AHM dengan kecepatan $600 \mathrm{Rpm}$ dan beban $10 \mathrm{~kg}$ hasil pengukuran kekasaran permukaan ditunjukkan pada tabel 2. Roda gigi UKM tanpa perlakuan melalui proses running-in dengan kecepatan 600 Rpm dan beban $10 \mathrm{~kg}$ ditunjukkan pada tabel 3.

Tabel 2. Data kekasaran permukaan produk AHM setelah running-in pada kecepatan $600 \mathrm{Rpm}$ dan beban $10 \mathrm{~kg}$.

\begin{tabular}{|c|c|c|c|c|c|c|c|c|}
\hline \multirow[t]{2}{*}{ Parameter } & \multicolumn{8}{|c|}{ Waktu [menit] } \\
\hline & $\overline{0}$ & 5 & 10 & 15 & 20 & 30 & 45 & 60 \\
\hline $\mathrm{Ra}[\mu \mathrm{m}]$ & $\mathbf{0 , 5 5 0}$ & 0,508 & 0,479 & 0,403 & 0,336 & 0,260 & 0,213 & 0,172 \\
\hline $\mathrm{Rq}[\mu \mathrm{m}]$ & 0,662 & 0,633 & 0,621 & 0,498 & 0,421 & $\mathbf{0 , 3 3 0}$ & 0,259 & 0,231 \\
\hline
\end{tabular}

Tabel 3. Data kekasaran permukaan produk UKM tanpa perlakuan setelah running-in pada kecepatan 600 Rpm dan

\begin{tabular}{cccccccc}
\multicolumn{7}{c}{ beban 10 kg. } \\
\hline Parameter & $\mathbf{0}$ & $\mathbf{5}$ & $\mathbf{1 0}$ & $\mathbf{1 5}$ & $\mathbf{2 0}$ & $\mathbf{3 0}$ & $\mathbf{4 5}$ \\
$\operatorname{nyyyyyy}[\mu \mathrm{m}]$ & $\mathbf{0 , 8 3 0}$ & $\mathbf{0 , 7 6 0}$ & $\mathbf{0 , 6 6 8}$ & $\mathbf{0 , 6 6 6}$ & $\mathbf{0 , 6 3 5}$ & $\mathbf{0 , 4 2 3}$ & $\mathbf{0 , 3 8 6}$ \\
& & & & & & & \\
Rq $[\mu \mathrm{m}]$ & $\mathbf{1 , 1 6 9}$ & $\mathbf{0 , 9 5 4}$ & $\mathbf{0 , 8 9 8}$ & $\mathbf{0 , 8 4 2}$ & $\mathbf{0 , 8 2 2}$ & $\mathbf{0 , 5 5 9}$ & $\mathbf{0 , 4 9 8}$ \\
\hline
\end{tabular}

Terlihat bahwa trend kekasaran permukaan Ra semakin menurun seiring dengan bertambahnya waktu runningin. Koefisien gesek pada saat running-in roda gigi produk AHM dengan kecepatan $600 \mathrm{rpm}$ dan beban $10 \mathrm{~kg}$ ditunjukkan pada gambar 9a. Koefisien gesek pada saat running-in roda gigi produk UKM dengan kecepatan 600 rpm dan beban $10 \mathrm{~kg}$ ditunjukkan pada gambar 9b. Trend koefisien gesek roda gigi sesuai dengan bentuk kurva running-in yang dikemukakan oleh Blau pada gambar 2. Roda gigi AHM memiliki koefisien gesek awal sebesar 0,21. Seiring dengan waktu, koefisien gesek ini semakin naik sampai mencapai keadaan steady state. Koefisien gesek steady state sebesar 0,41. Koefisien gesek roda gigi UKM lebih tinggi dibanding roda gigi AHM. Hal ini dikarenakan kekasaran permukaan roda gigi UKM lebih tinggi dibanding AHM. Roda gigi UKM memiliki koefisien gesek awal sebesar 0,24. Seiring dengan waktu, koefisien gesek ini semakin naik sampai mencapai keadaan steady state. Koefisien gesek steady state sebesar 0,43. Nilai kekasaran permukaan sangat berpengaruh pada koefisien gesek. Kekasaran yang tinggi akan menimbulkan koefisien gesek yang tinggi pula. 


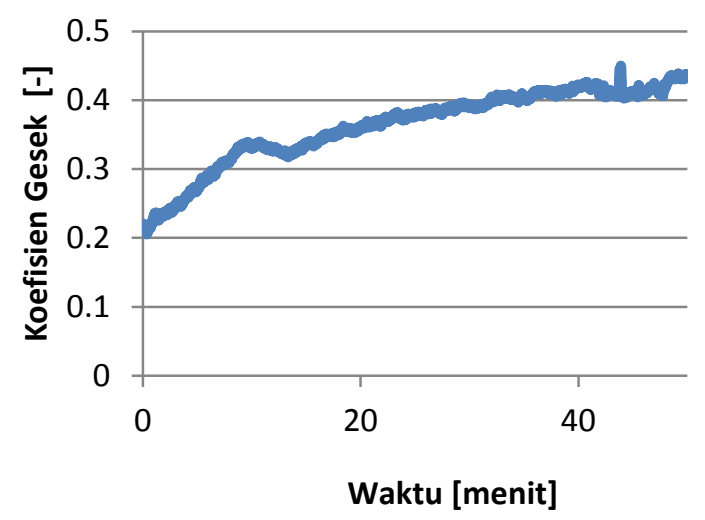

(a)

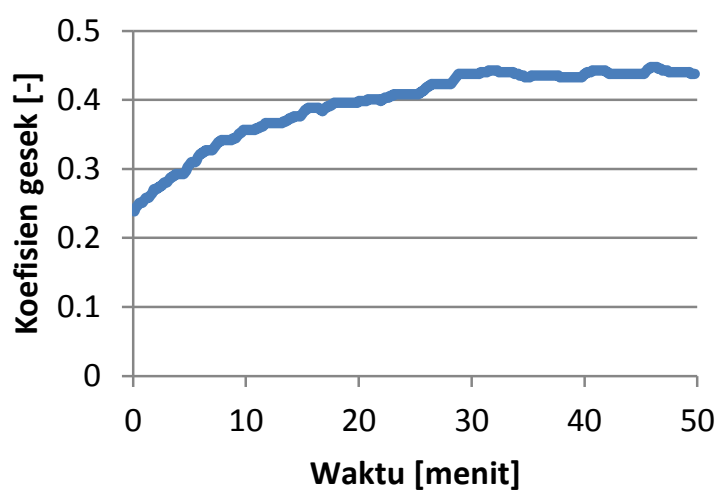

(b)

Gambar 9. (a). Koefisien gesek roda gigi produk AHM, (b). Koefisien gesek roda gigi produk UKM

Roda gigi produk AHM memiliki kekerasan yang memenuhi standar internasional yaitu 80 HRA di tepi gigi dan menurun kekerasannya menuju ke arah tengah. Roda gigi UKM memiliki kekerasan sebesar 61 HRA, karena memang belum mengalami perlakuan pengerasan dan material homogen sehingga nilai kekerasan merata di semua permukaan. Nilai kekerasan ini berpengaruh pada proses running-in, pada penelitian ini roda gigi produk AHM mempunyai waktu running-in sampai tercapai keadaan steady state selama 45 menit. Sedangkan roda gigi produk UKM mempunyai waktu running-in selama 40 menit. Produk UKM memiliki waktu mencapai steady state lebih cepat dibandingkan produk AHM. Hal ini dikarenakan produk UKM lebih lunak atau kekerasannya lebih rendah dibanding produk AHM.

\section{KESIMPULAN}

Dari hasil penelitian bisa ditarik kesimpulan bahwa nilai kekerasan permukaan memiliki pengaruh terhadap waktu running-in. Roda gigi yang memiliki nilai kekerasan tinggi akan lebih lama mencapai keadaan steady state. Pada penelitian ini roda gigi produk AHM mempunyai waktu running-in sampai tercapai keadaan steady state selama 45 menit. Sedangkan roda gigi produk UKM mempunyai waktu running-in selama 40 menit.

Nilai kekasaran permukaan sangat berpengaruh pada koefisien gesek. Kekasaran yang tinggi akan menimbulkan koefisien gesek yang tinggi pula. Roda gigi produk AHM pada kecepatan 600 rpm memiliki koefisien gesek 0,41. Roda gigi produk UKM Pada kecepatan 600 rpm memiliki koefisien gesek 0,43.

Dalam hal ini roda gigi produk UKM memiliki waktu running-in lebih singkat dibandingkan produk AHM, tetapi memiliki koefisien gesek yang lebih tinggi. Kelemahan ini bisa diatasi dengan memperhalus permukaan sehingga kekasaran permukaan lebih rendah dengan cara grinding. Serta mengeraskan permukaan dengan cara induction heating dan quenching.

\section{REFERENSI}

[1] Akbarzadeh, S., Khonsari, M.M., 2011, "Experimental and theoritical investigation of running-in", Tribology International 44, pp. 92-100.

[2] Jamari, 2006, "Running-in of Rolling Contacts", PhD Thesis, Unversity of Twente, Enschede, The Netherlands.

[3] Kraghelsky, V., Dobychun, M.N. and Kombalov, V.S., 1982, "Friction and Wear Calculation Methods", Pergamon Press, Oxford.

[4] Summer-Smith, J.D., 1994, “An Introductory Guide to Industrial Tribology”, Mechanical Engineering Publications Limited, London.

[5] Dhanasekaran, S., Gnanamoorthy R., 2008, "Gear tooth wear in sintered spur gears under dry running conditions", Wear 265, pp. 81-87.

[6] Whitehouse, D.J., 1994, "Handbook of Surface Metrology”, Institute of Physics Publishing.

[7] Blau, P.J., 2005, “On the nature of running-in”, Tribology International, Volume 38 (2005), Pages 1007-1012.

[8] Sjöberg, S., Björklund, S., Olofsson, U., 2011, "The influence of manufacturing method on the running-in of gears", Journal of Engineering Tribology 225:999.

[9] Evans, H.P., Snidle, R.W., Sharif, K.J., 2009, "Deterministic mixed lubrication modelling using roughness measurements in gear applications", Tribology International 42, pp. 1406-1417.

[10] Blau, P.J., 1996. “Friction Science and Technology”, Marcel Dekker, New York, USA. 